\title{
Kuraklık Stresine Karşı Bor Bileşiklerinin Soyada (Glycine max. L.) Büyüme Parametrelerine Etkisi
}

\author{
Mahmut DOĞAN*, Aslıhan AVU \\ Harran Üniversitesi, Fen-Edebiyat Fakültesi, Biyoloji Bölümü, Osmanbey Kampüsü, ŞANLIURFA
}

\section{Özet}

Bu çalışmada materyal olarak soya (Glycine max. L.) tohumları farklı bor bileşiklerinden oluşan, kontrollü koşullarda $\left(25 \pm 2{ }^{\circ} \mathrm{C}\right)$ yetiştirilmiştir. Çalışmada sırasıyla; potasyum tetraborat tetrahidrat, amonyum tetraborat tetrahidratt ve sodyum bor hidrürden 1 $\mathrm{mg} / \mathrm{l}$, lityum tetraborat tetrahidratt ve sodyum tetraborat dekahidrattan $100 \mathrm{mg} / \mathrm{l}$ olmak üzere 5 grup belirlenmiştir. Kullanılan dozlar daha önce yapılan ön çalışmada belirlenmiştir. Soya fideleri zamana bağlı olarak (kontrol, 3, 6, 9, 12, 15 ve 18 gün) farklı kuraklık uygulamalarına maruz bırakılarak yapraklarda klorofil, MDA, prolin ve iyon miktarları ölçülmüştür. Kuraklık stresine karşı bor bileşiklerinin uygulanması amacıyla yapılan araştırmada, soya bitkisinin bor bileşiklerine karşı tolerans sınırlarının çok dar olduğu saptanmıştır. Araştırmada stres+potasyumlu bor grubunda, klorofil ve prolin miktarı artmış, MDA miktarı kontrolle aynı seviyelerde olduğu tespit edilmiştir. Bu sonuçlara göre potasyum tetraboratın $0.1 \mathrm{mg} / 1$ doz uygulamasının en uygun eşik değeri olduğu ve kuraklığa karşı tüm parametrelerin birbirlerini destekler nitelikte olduğu ve en iyi sonucu verdiği tespit edilmiştir.

Anahtar Kelimeler: Bor, kuraklık stresi, prolin, soya

\section{The Effects of Boron Compounds on Growth Parameters of Soybean (Glycine max.} L.) Under Drought Stress

\begin{abstract}
In this study, soybean seeds (Glycine max. L.) were grown under controlled conditions $\left(25 \pm 2{ }^{\circ} \mathrm{C}\right)$ composed of different boron compounds. In the study, 5 groups were determined respectively as potassium tetraborate tetrahydrate $(1 \mathrm{mg} / 1)$, ammonium tetraborate tetrahydrate $(1 \mathrm{mg} / 1)$, sodium boron hydride $(1 \mathrm{mg} / 1)$, lithium tetraborate tetrahydrate $(100 \mathrm{mg} / 1)$, and sodium tetraborate decahydrate $(100 \mathrm{mg} / 1)$. The doses used in this study were determined according to the results of a preliminary study. Soybean seeds were exposed to different amounts of drought stress based on time (control, 3, 6, 9, 12, 15, and 18 days). Chlorophyll, MDA, amounts of proline and ion in leaf samples were measured. In this study which was conducted in order to apply boron compounds against drought stress, it was determined that tolerance limits of soybean plant for boron compounds is very narrow. In the study, it was revealed that amounts of chlorophyll and proline increased in stress+potassium boron group while the amount of MDA was the same as in the control group. According to the results, it was determined that $0.1 \mathrm{mg} / 1$ potassium tetraborate application was the most appropriate threshold level and that all the parameters supported each other against the drought and yielded the best results.
\end{abstract}

Keywords: Boron, drought stress, proline, soybean

*e-mail: dogan@harran.edu.tr 


\section{Giriş}

Bitki büyümesini engelleyen her faktör stres olarak tanımlanmaktadır [1]. Dünyanın birçok yerinde kuraklık, tuzluluk, aşırı sulama, yüksek ve düşük sıcaklık, $\mathrm{pH}$ ve ağır metallerin neden olduğu stresler yaygın olarak görülmektedir [2]. Son yıllarda çevresel bir sorun olan küresel isınmanın etkisiyle birlikte, tarımsal kuraklık ile suyun önemi hissedilmeye başlanmışırır [3]. Bitkiler kuraklık stresine karşı fizyolojik, biyokimyasal ve moleküler cevap niteliğinde, çevresel şartlara adapte olmayı sağlayacak tolerans mekanizmaları geliştirmektedirler [4]. Kuraklık stresinin bitkinin gelişimi ve verimi üzerindeki etkisi; stresin meydana geldiği gelişme dönemi ile stresin şiddeti ve süresine bağlı olarak değişmektedir [5]. Verimdeki azalmanın temel nedeni, başak oluşumu ve çiçeklenme sonrası yaprak alanı üzerindeki olumsuz etkiden kaynaklanmaktadır [2]. Basak oluşumu dönemindeki kuraklık stresi başaktaki tane sayısının azalmasına neden olurken, çiçeklenmeden sonraki kuraklık tanedeki ağırlık azalışına sebep olmaktadır [6]. Son yıllarda atmosfere atılan sera gaz miktarının hızla artması sonucunda küresel ısınma felaketi ile karşı karşıya kalınmıştır [7]. Küresel ısınma sonucunda iklim değişimleri yaşanmaya başlanmıştır [1]. Bu iklim değiş̧imleri ülkemiz gibi kurak ve yarı kurak alanlarda yer alan ülkelerde kendisini daha fazla hissettirmeye başlamıştır [6]. Türkiye kurak ve yarı kurak iklim kuşağında yer aldığından, çok önemli ekonomik değere sahip olan bitkileri susuz şartlarda yetiştirmek mümkün değildir [8].

Bor'un bitkilerdeki önemi bitkilerin iç beslenme koşullarının oluşturulmasında ortaya çıkmaktadır [9]. Bor bitkilerde çiçeklenmenin kontrolünde, polen üretiminde, tohum ve meyve gelişiminde önemli rol oynamaktadır [10]. Bor doğal olarak toprakta bulunmasına rağmen, bazı bölgelerdeki yoğun yağışlar, coğrafik koşullar ve tarım yöntemlerindeki farklı uygulamalar nedeniyle oranı azalmaktadır [11]. Toprakta bor miktarı, bitkilerin ihtiyacı olan ve yukarda belirtilen fonksiyonları yerine getiremeyecek oranlara düştüğünde, borlu gübrelerin kullanılması bitkilerin yetişmesinde önemli rol oynamaktadır [12 ve 8]. Bazı çalışmalarda kullanılacak bor miktarının hektar başına 0.2 ila $4 \mathrm{~kg}$ arasında değiştiği rapor edilmiştir [13]. Pamuk, mısır, soya fasulyesi gibi bazı bitkilerde daha yüksek oranda Bor’a ihtiyaç olduğu bildirilmiştir [14]. Topraklarda Bor toksisitesi doğal olarak oluşabildiği gibi, aynı zamanda yüksek bor oranına sahip sular ile yapılan yetiştiricilik sonucunda da ortaya çıkabilmektedir [15]. Sulama suyunda bulunan $1 \mathrm{mg} / \mathrm{l}$ Bor, duyarlı bitkilerde kolayca gözle görülebilen toksisite belirtilerine yol açabilmektedir [16]. Bora dayanıklı bitkilerde ise bu değer $10 \mathrm{mg} / \mathrm{kg}$ olduğunda, toksisite belirtileri görülmektedir [17].

Kuraklık tüm doğal afetler içinde insanlık için en yüksek risk taşıyan bir afettir. Genel olarak, kuraklık yağışın, yeraltı veya yüzey sularının ortalamalarının altında olması olarak tanımlanmaktadır. Kuraklık, meteorolojik, hidrolojik, tarımsal ve sosyo ekonomik kuraklık olarak dört gruba ayrılabilir. Sıcaklık artış1 ile bitkilerin fotosentez ve solunum dengesi bozulacağından, bitkilerde büyüme yavaşlar ve bir durgunluk dönemi görülür. $\mathrm{Bu}$ artış, uzun süreli olursa bitki toprak üstü organlarıyla devamlı kaybettiği suyu kökleriyle karşılayamaz. Bitkinin devamlı su kaybetmesi, protoplazmanın pihtılaşmasına ve bitkinin ölümüne yol açar. Son yıllarda kurak ve yarı kurak bölgelerde bor toksisitesinin sıkça görülmesi sonucu, bora dayanıklı çeşitlerin belirlenmesi, soyada bor kullanılması ve ayrıca bor ile diğer bitki besin maddeleri arasında ilişkilerin olup olmadığını belirleme çalışmalarına hız verilmiştir. 
$\mathrm{Bu}$ çalışmada ülkemiz tarımı ve ekonomisinde önemli yeri olan soya (Glycine max. L., cv., "A3935") bitkisine kuraklık stresi ile farklı bor bileşikleri uygulanmıştır. Bu doğrultuda klorofil, MDA, prolin ve iyon analizlerinin yapılması planlanmıştır. Elde edilen bulguların değerlendirilmesi, borun kuraklık stresinde oynadığı muhtemel rolün aydınlatılması, büyüme parametrelerinin birlikte değerlendirilmesi amaçlanmıştır.

\section{Materyal ve yöntem}

Çalı̧̧ma materyali olarak soya (Glycine max. L., cv., "A3935") tohumları Potasyum tetraborat tetrahidrat $\left(\mathrm{K}_{2} \mathrm{~B}_{4} \mathrm{O}_{7} \cdot 4 \mathrm{H}_{2} \mathrm{O}\right)$, Amonyum tetraborat tetrahidrat $\left.\left(\left(\mathrm{NH}_{4}\right)_{2} \cdot \mathrm{B}_{4} \mathrm{O}_{7} \cdot 4 \mathrm{H}_{2} \mathrm{O}\right)\right)$, Sodyum bor hidrür $\left(\mathrm{NaBH}_{4}\right)$, Lityum tetraborat tetrahidrat $\left(\mathrm{Li}_{2} \mathrm{~B}_{4} \mathrm{O}_{7} \cdot 4 \mathrm{H}_{2} \mathrm{O}\right)$, Sodyum tetraborat dekahidrat $\left(\mathrm{Na}_{2} \mathrm{~B}_{4} \mathrm{O}_{7} \cdot 10 \mathrm{H}_{2} \mathrm{O}\right)$ içeren farklı uygulamalar şeklinde kontrollü koşullarda $\left(25 \pm 2{ }^{\circ} \mathrm{C}\right)$ yetiştirilmiştir. Deney kontrol grubu ve diğer gruplar sirasıyla; Potasyum tetraborat tetrahidrattan $0.1 \mathrm{mg} / \mathrm{l}$, Amonyum tetraborat tetrahidrattan 1 $\mathrm{mg} / \mathrm{l}$, Sodyum bor hidrürden $1 \mathrm{mg} / \mathrm{l}$, Lityum tetraborat tetrahidrattan $100 \mathrm{mg} / \mathrm{l}$, Sodyum tetraborat dekahidrattan 100 mg/l olmak üzere 6 grup şeklinde uygun dozlar kullanılmıştır. Doz miktarları ön çalışmalarda en uygun eşik değerleri olarak tespit edilip esas denemede kullanılmaya karar verilmiştir. Çalışmada kontrol grubu, sadece kuraklık stresi uygulanan grup, kuraklık stresi+borun 5 farklı bileşiklerinin uygulandığı grup olmak üzere toplam 7 ortamda, soya fidelerinin verdiği tepkiler araştırılmıştır.

Çimlenme ve büyüme evresini kapsayan tüm denemeler iklim odasında $25 \pm 2{ }^{\circ} \mathrm{C}$ sıcaklık ve $\%$ $65 \pm 5$ 'e ayarlanmış bağıl nem deney süresince sabit tutulmuştur. Işık şiddeti bitki yaprak yüzeyinden 13000 lux 1şık yoğunluğu olacak şekilde ayarlanmıştır. Sağlam ve benzer büyüklükte seçilen tohumlar Ellis ve ark. [18]'nın yöntemine göre yüzeysel sterilizasyon yapılarak tohumlar çimlendirme kaplarına alınmıştır. Çimlenmiş tohumları tespit edebilmek için tohumların inkübe edildiği günü izleyen 5. günde sayım yapılarak, çimlenme için radikulanın testadan çıkmış olması esas kabul edilmiştir. Çimlenen tohumlar saksılarda perlit ortamına alınarak, ilk gerçek yapraklar çıkmaya başlayıncaya kadar [19] besin çözeltisiyle sulanmışlardır.

Son aşamada kontrol grubuna ve kuraklık stresi grubuna sadece hoagland besin çözeltisi, kuraklık stresi+bor guruplarına hoagland besin çözeltisiyle beraber borun farklı bileşikleri belirlenen dozlarda uygulanmıştır. Deneme; çimlenme aşaması 6 gün, ilk gerçek yaprakların oluşum aşaması 14 gün, hoagland besin çözeltisi ile beraber bor uygulanmış olan aşama 12 gün olmak üzere toplam 31 gündür. 31. günün sonunda 3 er gün arayla kontrol grubundan, kuraklık stresi ve kurakl1k+ bor uygulanmış ortamlarda yetişen bitkilerden 5 defa örnek alınmıştır. Böylece 6 gün, 9 gün, 12 gün, 15 gün ve 18 gün kuraklık stresi ile kuraklık artı bor stresi uygulanmış tüm ortamlardan örnekler alınmıştır.

Bitki yaprak örneklerinde klorofil belirlenmesi Luna ve ark., [20] göre; bitki yapraklarından bilinen miktarda alınan taze örnekler \% 80'lik $10 \mathrm{ml}$ etanol içine konmuş ve su banyosunda $80^{\circ} \mathrm{C}$ 'de 20 dakika bekletildikten sonra 654 nm'de absorbans (A) değerleri spektrofotometrede (Shimadzu UV-1208) okunmuştur. Yaprak dokularındaki klorofil miktarı toplam klorofil $\mu \mathrm{g} / \mathrm{mg}$ toplam ağırlık (T.A) olarak hesaplanmıştır.

MDA miktarı Lutts ve ark. [21]'nın yöntemi esas alınarak belirlenmiştir. Bu yönteme göre $-80{ }^{\circ} \mathrm{C}$ de donmuş olan örneklerden $200 \mathrm{mg}$ yaş yaprak örneği alınmış, bunun üzerine $5 \mathrm{ml} \% 0.1^{\prime}$ lik Trichloro 
Aceticacid (TCA) ilave edilmiş ve bu karışım 12500 rpm’de 20 dakika süreyle santrifüj edilmiştir. 5 ml'lik ekstrakttan $3 \mathrm{ml}$ süpernatant alınarak, üzerine \% 20 Thiobarbütiric Acid (TBA) bulunan \% 0.1'lik $3 \mathrm{ml}$ TCA ilave edilmiştir. $95{ }^{\circ} \mathrm{C}$ ' deki sıcak su banyosunda 30 dakika bekletilen karışımın, 532 ve 600 nm'de absorbans değerleri spektrofotometrede (Shimadzu UV-1208) okunmuştur. Kör olarak, içinde \% 20 TBA bulunan \% 0.1'lik TCA kullanılmıştır. Yaprak dokularındaki MDA miktarı, $\mu$ mol/g T.A. olarak hesaplanmıştır.

İyon analizleri (Sodyum, potasyum, kalsiyum ve klor) kurutulmuş yaprak örneklerinde Taleisnik ve ark. [22] 'ın yöntemine göre tayin edilmiştir. Buna göre; etüvde $105^{\circ} \mathrm{C}$ ve 48 saat kurutulan örnekler porselen havanda öğütülerek toz haline getirilmiştir. Daha sonra, her bitki yaprağından hassas teraziyle tartılan 0.5 gr alınan örnekler, deney tüpleri içine alınarak üzerine $1 \mathrm{~N}$ Nitrik asitten $\left(\mathrm{HNO}_{3}\right) 10 \mathrm{ml}$ ilave edilerek homojenize edilip 20 dakika süreyle çalkalayıcıda çalkalanmıştır. Homojenize edilen örnekler 95 ${ }^{\circ} \mathrm{C}$ de bir saat su banyosunda bekletildikten sonra, soğutularak $3500 \mathrm{rpm}$ de 10 dakika santrifüj edilmiştir. Süpernatant kısmı alınarak $10 \mathrm{ml}$ daha $1 \mathrm{~N} \mathrm{HNO}_{3}$ ilave edilerek aynı işlem tekrarlanmış, işlem sonunda alınan süpernatant kısmı bilinen hacime tamamlanmıştır. Bu şekilde hazırlanan ekstraktlar da sodyum $\left(\mathrm{Na}^{+}\right)$, potasyum $\left(\mathrm{K}^{+}\right)$, kalsiyum $\left(\mathrm{Ca}^{++}\right)$ve klor $\left(\mathrm{Mg}^{+}\right)$iyonları ICP cihazı (Perkim Elmer, OES, Optima 5300 DV) ile analiz edilmiş absorbans değerleri $\mu \mathrm{g} / \mathrm{mg}$ Kuru Ağırlık (K.A.) olarak hesaplanmıştır.

Yaprakta prolin analizi, Bates ve ark. [23] 'nin geliştirildiği yöntem kullanılarak yapılmıştır. Yaklaşık $0.5 \mathrm{~g}$ taze yaprak örneği $10 \mathrm{ml}$ \%3'lük Sulfosalisik asit ile homojenize edilmiştir. Filitre edilen örnekler 1 saat süresince $100{ }^{\circ} \mathrm{C}$ ' ye ayarlı su banyosunda ninhidrin ile reaksiyona sokulmuş ve devamında örnekler buz banyosuna alınarak reaksiyon tamamlanmıştır. Soğutma işleminden sonra ortam toluen ile ekstrakte edilmiş ve pembemsi-kırmızı renkte, standart olarak L prolin kullanılarak, 520 nm'de spektrofotometrede (Shimadzu UV-1208) okunarak absorbans değerleri $\mu \mathrm{mol} / \mathrm{mg}$ T.A. olarak hesaplanmıştır.

Çalışma 3 tekrarlı olarak düzenlenmiş, her bir tekrarda 20 adet, tüm denemede ise 1200 adet tohum kullanılmıştır. Araştırma sonuçlarının önemliliği Minitab paket programı ile belirlenmiştir. Ortalamalar arasındaki farklılıkların önemliliği ise Mstat paket programı ile Duncan testi yapılarak karşılaştırılmıştır.

\section{Bulgular}

Ülkemizde bol miktarda bulunan bor bileşiklerinin kuraklık stresine karşı muhtemel etkilerini tespit etmek amacıyla yapılan bu çalışmada birçok parametrenin bor bileşikleriyle olan ilişkisi araştırılarak aşağıdaki bulgular elde edilmiştir. $\mathrm{Bu}$ amaçla klorofil, MDA, iyon ve prolin analizleri yapılmıştır (Tablo 1, 2, 3, 4). Yapılan analiz sonuçlarına göre klorofil oranı kontrol grubunun 6. gününde $128 \pm 1 \mu \mathrm{mol} / \mathrm{mg}$ T.A. ve 18 . gününde $124 \pm 1 \mu \mathrm{mol} / \mathrm{mg}$ T.A. olurken, kuraklık stresi grubunun 6 . gününde $99 \pm 2 \mu \mathrm{mol} / \mathrm{mg}$ T.A. 18. gününde $94 \pm 2 \mu \mathrm{mol} / \mathrm{mg}$ T.A. olarak ölçülmüş, Stres+ Potasyum tetraborat tetrahidrat grubunda ise $115 \pm 1 \mu \mathrm{mol} / \mathrm{mg}$ T.A. ve 18. gününde $113 \pm 4 \mu \mathrm{mol} / \mathrm{mg}$ T.A. olduğu ölçülmüştür (Tablo 1). Yaprakların klorofil içeriği ile ilgili tüm ortamlarda yapılan analizlerde, sonuçların kontrolden düşük çıktığı belirlenmiştir. Stres şiddetinin arttığı 18. günde, Potasyumlu bor ortamında herhangi bir azalma meydana gelmezken diğer gruplarda klorofil oranının azaldığı tespit edilmiştir. Stres şartlarında klorofil miktarının azaldığı daha önce yapılan birçok çalışmada rapor edilmiştir [23-26]. MDA miktarı 
Tablo 2'de incelendiğinde kontrolün 6. gününde $48 \pm 1 \mu \mathrm{mol} / \mathrm{mg}$ T.A. ve 18 . gününde $49 \pm 2 \mu \mathrm{mol} / \mathrm{mg}$ T.A. olurken, kurakl1k stresi grubunun 6. gününde $59 \pm 1 \mu \mathrm{mol} / \mathrm{mg}$ T.A. ve 18 . gününde $63 \pm 1 \mu \mathrm{mol} / \mathrm{mg}$ T.A. bulunmuş, Stres + Potasyum tetraborat tetrahidrat grubunda ise $49 \pm 1 \mu \mathrm{mol} / \mathrm{mg}$ T.A. ve 18 . gününde $47 \pm 2$ $\mu \mathrm{mol} / \mathrm{mg}$ T.A. olduğu ölçülmüştür. Analiz sonuçlarına göre MDA miktarının demene süresince aynı kalması potasyum tetraborattetrahidrat ve borun birlikte kullanılması, kuraklık stresine karşı olumlu bir etki yaptığının göstergesi olarak ifade edilebilir.

Tablo 1. Kuraklık stresi ve bor uygulanan soya (Glycine max. L.) fidelerinden elde edilen sonuçlarda klorofil miktarı

\begin{tabular}{llllll}
$\mu$ mol/mg T.A. olarak hesaplanmıştır. (Değerler üç tekrarın ortalaması \pm standart hata olarak verilmiştir $(\mathrm{P}<0.05)$ ). \\
\hline Uygulamalar & 6. gün & 9 . gün & 12. gün & 15. gün & 18 . gün \\
\hline Kontrol & $128 \pm 1$ & $127 \pm 2$ & $127 \pm 2$ & $125 \pm 2$ & $124 \pm 1$ \\
Kurakllk Stresi & $115 \pm 1$ & $115 \pm 1$ & $113 \pm 2$ & $113 \pm 2$ & $113 \pm 4$ \\
Stres+ Potasyum tetraborat tetrahidrat & $99 \pm 2$ & $95 \pm 1$ & $95 \pm 1$ & $96 \pm 1$ & $94 \pm 2$ \\
Stres+ Amonyum tetraborat tetrahidrat & $84 \pm 3$ & $84 \pm 3$ & $82 \pm 1$ & $80 \pm 2$ & $78 \pm 1$ \\
Stres+ Sodyum bor hidrür & $81 \pm 2$ & $82 \pm 2$ & $82 \pm 3$ & $80 \pm 4$ & $79 \pm 2$ \\
Stresi +Lityum tetraborat tetrahidrat & $88 \pm 1$ & $84 \pm 1$ & $84 \pm 2$ & $82 \pm 2$ & $80 \pm 1$ \\
Stres+ Sodyum tetraborat dekahidrat & $77 \pm 2$ & $75 \pm 2$ & $70 \pm 1$ & $69 \pm 1$ & $66 \pm 2$ \\
\hline
\end{tabular}

Stres+

Bu sonuçlar aşağıdaki birçok çalışmayla desteklenmektedir. Artan kuraklık stresine bağlı olarak soya membranlarında oluşan MDA içeriğindeki artış oksidatif hasarın bir göstergesi olarak kabul edilmektedir [24-26]. Sonuç olarak Potasyum tetraborat tetrahidrat'ın oksidatif stresi engellediği ve böylelikle MDA miktarını düşürdüğü tespit edilmiştir. Diğer gruplarda MDA miktarı kontrol ve kuraklık stres gruplarına oranla oldukça yüksek çıkmıştır.

Tablo 2. Kuraklık stresi ve bor uygulanan soya (Glycine max. L.) fidelerinden elde edilen sonuçlarda MDA miktarı

\begin{tabular}{llllll}
$\mu \mathrm{mol} / \mathrm{mg}$ T.A. olarak hesaplanmiştır. (Değerler üç tekrarın ortalaması \pm standart hata olarak verilmiştir $(\mathrm{P}<0.05)$ ). \\
\hline Uygulamalar & 6 . gün & 9 . gün & 12. gün & 15. gün & 18 . gün \\
\hline Kontrol & $48 \pm 1$ & $47 \pm 2$ & $47 \pm 2$ & $45 \pm 3$ & $49 \pm 2$ \\
Kuraklık Stresi & $59 \pm 1$ & $65 \pm 1$ & $65 \pm 1$ & $66 \pm 2$ & $63 \pm 1$ \\
Stres+ Potasyum tetraborat tetrahidrat & $49 \pm 1$ & $52 \pm 2$ & $49 \pm 2$ & $45 \pm 1$ & $47 \pm 2$ \\
Stres+ Amonyum tetraborat tetrahidrat & $62 \pm 2$ & $64 \pm 3$ & $74 \pm 3$ & $73 \pm 2$ & $77 \pm 3$ \\
Stres+ Sodyum bor hidrür & $67 \pm 1$ & $68 \pm 1$ & $74 \pm 1$ & $66 \pm 3$ & $76 \pm 2$ \\
Stresi +Lityum tetraborat tetrahidrat & $64 \pm 1$ & $69 \pm 2$ & $76 \pm 2$ & $68 \pm 2$ & $68 \pm 1$ \\
Stres+ Sodyum tetraborat dekahidrat & $65 \pm 1$ & $67 \pm 1$ & $69 \pm 2$ & $72 \pm 1$ & $73 \pm 2$ \\
\hline
\end{tabular}

MDA (gün $\mathrm{P}=0.020$, stres $\mathrm{P}=0.041$ )

Prolin miktarı kontrolün 6. gününde $4.6 \pm 1 \mu \mathrm{mol} / \mathrm{mg}$ T.A. ve 18 . gününde $4.7 \pm 2 \mu \mathrm{mol} / \mathrm{mg}$ T.A. olurken, kuraklık stresi grubunun 6. gününde $7.7 \pm 1 \mu \mathrm{mol} / \mathrm{mg}$ T.A. ve 18 . gününde $15.5 \pm 1 \mu \mathrm{mol} / \mathrm{mg}$ T.A. bulunmuş, Stres + Potasyum tetraborat tetrahidrat uygulamalarında ise $6.6 \pm 1 \mu \mathrm{mol} / \mathrm{mg}$ T.A. ve 18 . gününde $21.8 \pm 2 \mu \mathrm{mol} / \mathrm{mg}$ T.A. olduğu ölçülmüştür (Tablo 3). Kuraklıkla birlikte prolin miktarında ki artış istatistiksel olarak anlamlı $(\mathrm{p}<0.05)$ bulunmuştur. Potasyum tetraborat tetrahidrat ortamında önemli artış tespit edilmiştir. 9. ve sonrasındaki tüm günlerde Potasyum tetraborat tetrahidrat grubunda prolin miktarı kontrol grupları dâhil diğer tüm gruplara oranla daha yüksek çıktığı tespit edilmiştir.

Tablo 3. Kuraklık stresi ve bor uygulanan soya (Glycine max. L.) fidelerinden elde edilen sonuçlarda prolin miktarı $\mu \mathrm{mol} / \mathrm{mg}$ T.A. olarak hesaplanmıştır. (Değerler üç tekrarın ortalaması \pm standart hata olarak verilmiştir $(\mathrm{P}<0.05)$ ).

\begin{tabular}{llllll}
\hline Uygulamalar & 6. gün & 9 . gün & 12. gün & 15. gün & 18 . gün \\
\hline Kontrol & $4.6 \pm 1$ & $4.6 \pm 2$ & $4.5 \pm 2$ & $4.7 \pm 3$ & $4.7 \pm 2$ \\
Kuraklık Stresi & $7.7 \pm 1$ & $8.5 \pm 1$ & $8.9 \pm 1$ & $10.8 \pm 2$ & $15.5 \pm 1$ \\
Stres+ Potasyum tetraborat tetrahidrat & $6.6 \pm 1$ & $9.7 \pm 2$ & $13.6 \pm 2$ & $17.8 \pm 1$ & $21.8 \pm 2$ \\
Stres+ Amonyum tetraborat tetrahidrat & $6.5 \pm 2$ & $6.7 \pm 3$ & $7.1 \pm 3$ & $7.9 \pm 2$ & $8.8 \pm 3$ \\
Stres+ Sodyum bor hidrür & $7.9 \pm 1$ & $7.5 \pm 1$ & $7.9 \pm 1$ & $8.3 \pm 3$ & $9.8 \pm 2$ \\
Stresi +Lityum tetraborat tetrahidrat & $8.5 \pm 1$ & $8.8 \pm 2$ & $8.9 \pm 2$ & $9.9 \pm 2$ & $12.3 \pm 1$ \\
Stres+ Sodyum tetraborat dekahidrat & $9.4 \pm 1$ & $8.9 \pm 1$ & $10.9 \pm 2$ & $12.5 \pm 1$ & $13.1 \pm 2$ \\
\hline Prolin (gün $\mathrm{P}=0.016$, stres $\mathrm{P}=0.0134)$ & & & & &
\end{tabular}


Sodyum miktarı kontrolün 6. gününde $9.7 \pm 1 \mu \mathrm{mol} / \mathrm{mg}$ T.A. ve 18 . gününde $11.1 \pm 1 \mu \mathrm{mol} / \mathrm{mg}$ T.A. olurken, kuraklık stresi grubunun 6. gününde $31.7 \pm 1 \mu \mathrm{mol} / \mathrm{mg}$ T.A. ve 18. gününde $29.2 \pm 1$ $\mu \mathrm{mol} / \mathrm{mg}$ T.A. bulunmuş, Stres + Potasyum tetraborat tetrahidrat uygulamalarında ise $17.5 \pm 1 \mu \mathrm{mol} / \mathrm{mg}$ T.A. ve 18. gününde $15.9 \pm 2 \mu \mathrm{mol} / \mathrm{mg}$ T.A. olduğu ölçülmüştür (Tablo 4). $\mathrm{Na}^{+}$miktarı Potasyum tetraborat tetrahidratlı ortamda yetişen soya yapraklarında kontrole göre yüksek olup, diğer uygulamalara göre anlamlı derecede düşük seyrettiği gözlenmiştir. Elde edilen bu sonuçlar daha önce yapılan çalışmalarla da örtüşmektedir [2].

Potasyum miktarı kontrolün 6. gününde $25.1 \pm 1 \mu \mathrm{gr} / \mathrm{mg} \mathrm{K.A.} \mathrm{18.} \mathrm{gününde} 22.0 \pm 1 \mu \mathrm{gr} / \mathrm{mg}$ K.A., olurken, kurakl1k stresi grubunun 6. gününde $24.9 \pm 1 \mu$ gr/mg K.A. 18. gününde $27.2 \pm 2 \mu$ gr/mg K.A. bulunmuş, Stres + Potasyum tetraborat tetrahidrat uygulamalarında ise kontrolün 6 . gününde $34.2 \pm 1 \mu$

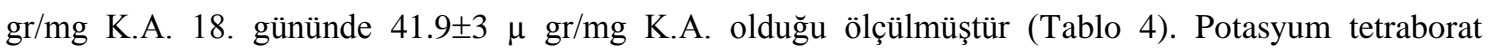
tetrahidratlı ortamda yetişen soya yapraklarının $\mathrm{K}^{+}$miktarı kontrole ve diğer uygulama ortamlarına göre anlamlı derecede yüksek bulunmuştur. Kuraklık şartlarında potasyum miktarının yüksek bulunması beklenen bir sonuç olarak görülmektedir [28].

Tablo 4. Kuraklık stresi ve bor uygulanan soya (Glycine max. L.) fidelerinden elde edilen sonuçlarda $\mathrm{Na}^{+}, \mathrm{K}^{+}, \mathrm{Ca}^{++}, \mathrm{Mg}^{+}$ ( $\mu$ gr/mg K.A.) olarak hesaplanmıştır. (Değerler üç tekrarın ortalaması \pm standart hata olarak verilmiştir $(\mathrm{P}<0.05)$.

\begin{tabular}{|c|c|c|c|c|c|}
\hline Uygulamalar & 6. gün & 9. gün & 12. gün & 15. gün & 18. gün \\
\hline Kontrol & $9.7 \pm 1$ & $9.6 \pm 1$ & $13.1 \pm 2$ & $10.3 \pm 3$ & $11.1 \pm 1$ \\
\hline Kuraklık Stresi & $31.7 \pm 1$ & $35.1 \pm 1$ & $29.4 \pm 1$ & $26.3 \pm 1$ & $29.2 \pm 1$ \\
\hline Stres+ Potasyum tetraborat tetrahidrat & $17.5 \pm 1$ & $15.4 \pm 1$ & $16.0 \pm 1$ & $17.3 \pm 1$ & $15.9 \pm 2$ \\
\hline $\mathrm{Na}^{+}$Stres+ Amonyum tetraborat tetrahidrat & $32.0 \pm 3$ & $32.4 \pm 4$ & $48.4 \pm 4$ & $35.7 \pm 4$ & $36.4 \pm 3$ \\
\hline Stres + Sodyum bor hidrür & $35.1 \pm 1$ & $35.7 \pm 2$ & $29.9 \pm 1$ & $36.4 \pm 2$ & $39.8 \pm 1$ \\
\hline Stresi +Lityum tetraborat tetrahidrat & $40.7 \pm 2$ & $41.8 \pm 1$ & $54.6 \pm 1$ & $54.3 \pm 1$ & $53.3 \pm 2$ \\
\hline Stres+ Sodyum tetraborat dekahidrat & $32.3 \pm 3$ & $33.5 \pm 3$ & $45.4 \pm 3$ & $36.5 \pm 3$ & $37.4 \pm 3$ \\
\hline Uygulamalar & 6. gün & 9. gün & 12. gün & 15. gün & 18. gün \\
\hline Kontrol & $25.1 \pm 1$ & $25.3 \pm 1$ & $20.5 \pm 2$ & $28.9 \pm 3$ & $22.0 \pm 1$ \\
\hline Kuraklık Stresi & $24.9 \pm 2$ & $29.0 \pm 5$ & $25.0 \pm 2$ & $25.6 \pm 2$ & $27.2 \pm 2$ \\
\hline Stres+ Potasyum tetraborat tetrahidrat & $34.2 \pm 1$ & $34.4 \pm 4$ & $36.7 \pm 3$ & $37.2 \pm 1$ & $41.9 \pm 3$ \\
\hline $\mathrm{K}^{+}$Stres+ Amonyum tetraborat tetrahidrat & $25.1 \pm 2$ & $25.3 \pm 3$ & $20.3 \pm 1$ & $23.4 \pm 3$ & $21.2 \pm 2$ \\
\hline Stres + Sodyum bor hidrür & $24.5 \pm 1$ & $16.9 \pm 5$ & $16.4 \pm 3$ & $15.9 \pm 6$ & $24.1 \pm 1$ \\
\hline Stresi +Lityum tetraborat tetrahidrat & $25.1 \pm 1$ & $25.3 \pm 2$ & $20.5 \pm 2$ & $28.9 \pm 4$ & $22.0 \pm 2$ \\
\hline Stres+ Sodyum tetraborat dekahidrat & $29.4 \pm 1$ & $19.9 \pm 2$ & $17.6 \pm 3$ & $25.8 \pm 2$ & $16.7 \pm 1$ \\
\hline Uygulamalar & 6. gün & 9. gün & 12. gün & 15. gün & 18. gün \\
\hline Kontrol & $28.5 \pm 1$ & $16.7 \pm 1$ & $22.3 \pm 2$ & $24.2 \pm 2$ & $26.3 \pm 2$ \\
\hline Kuraklık Stresi & $19.4 \pm 1$ & $15.7 \pm 2$ & $18.5 \pm 3$ & $17.3 \pm 4$ & $18.4 \pm 3$ \\
\hline Stres+ Potasyum tetraborat tetrahidrat & $29.9 \pm 2$ & $17.9 \pm 4$ & $14.5 \pm 2$ & $21.8 \pm 3$ & $26.6 \pm 2$ \\
\hline $\mathrm{Ca}^{++}$Stres+ Amonyum tetraborat tetrahidrat & $26.3 \pm 3$ & $25.2 \pm 3$ & $19.8 \pm 1$ & $17.5 \pm 1$ & $25.3 \pm 1$ \\
\hline Stres + Sodyum bor hidrür & $23.3 \pm 2$ & $24.3 \pm 1$ & $19.5 \pm 2$ & $19.1 \pm 1$ & $25.5 \pm 2$ \\
\hline Stresi +Lityum tetraborat tetrahidrat & $29.4 \pm 1$ & $19.9 \pm 3$ & $14.6 \pm 1$ & $25.8 \pm 2$ & $30.6 \pm 3$ \\
\hline Stres+ Sodyum tetraborat dekahidrat & $24.4 \pm 2$ & $19.5 \pm 2$ & $17.6 \pm 2$ & $25.8 \pm 2$ & $26.3 \pm 2$ \\
\hline Uygulamalar & 6. gün & 9. gün & 12. gün & 15. gün & 18. gün \\
\hline Kontrol & $23.1 \pm 2$ & $21.9 \pm 3$ & $24.2 \pm 3$ & $23.8 \pm 1$ & $24.1 \pm 3$ \\
\hline Kuraklık Stresi & $14.8 \pm 3$ & $15.3 \pm 3$ & $19.4 \pm 2$ & $13.7 \pm 1$ & $12.9 \pm 2$ \\
\hline Stres+ Potasyum tetraborat tetrahidrat & $16.4 \pm 2$ & $15.7 \pm 3$ & $22.2 \pm 1$ & $23.7 \pm 2$ & $28.5 \pm 2$ \\
\hline $\mathrm{Mg}^{+}$Stres + Amonyum tetraborat tetrahidrat & $11.5 \pm 3$ & $14.3 \pm 2$ & $16.5 \pm 2$ & $17.8 \pm 2$ & $18.5 \pm 2$ \\
\hline Stres + Sodyum bor hidrür & $13.5 \pm 2$ & $17.4 \pm 1$ & $18.6 \pm 3$ & $18.7 \pm 1$ & $14.9 \pm 2$ \\
\hline Stresi +Lityum tetraborat tetrahidrat & $15.3 \pm 3$ & $15.2 \pm 4$ & $12.2 \pm 2$ & $17.8 \pm 3$ & $13.9 \pm 1$ \\
\hline Stres+ Sodyum tetraborat dekahidrat & $19.4 \pm 2$ & $19.8 \pm 2$ & $17.6 \pm 3$ & $15.8 \pm 2$ & $16.4 \pm 2$ \\
\hline
\end{tabular}

Kalsiyum miktarı kontrolün 6. gününde $28.5 \pm 1 \mu$ gr/mg K.A. 18 . gününde $26.3 \pm 2 \mu$ gr/mg K.A., olurken, kuraklık stresi grubunun 6. gününde $19.4 \pm 1 \mu \mathrm{gr} / \mathrm{mg}$ K.A. 18. gününde $18.4 \pm 3 \mu$ gr/mg K.A. bulunmuş, Stres + Potasyum tetraborat tetrahidrat uygulamalarında ise kontrolün 6 . gününde $29.9 \pm 2 \mu$ gr/mg K.A. 18. gününde $26.6 \pm 2 \mu$ gr/mg K.A. olduğu ölçülmüştür (Tablo 4). Potasyum tetraborat 
tetrahidratlı ortamda yetişen soya yapraklarının $\mathrm{Ca}^{++}$düzeyi kontrole ve diğer uygulama ortamlarına göre anlamlı anlamlı bir artış izlemiştir $(\mathrm{P}<0.05)$. Stres + Potasyum tetraborat tetrahidrat ortamının 6 . gününde yüksek 18. günde ise azalan bir değişim izlemiştir. Aslında kalsiyum miktarının yüksek bulunması bazı çalışmalarda istenmeyen bir sonuç olarak rapor edilmiştir [29]. Ancak başka bir çalışmada ise kalsiyum miktarının yüksek bulunması hücre zarının sağlamlığına işaret ettiğinden önemli kabul edilmektedir [30 ve 31].

Magnezyum miktarı kontrolün 6. gününde $23.1 \pm 2 \mu \mathrm{gr} / \mathrm{mg} \mathrm{K}$.A. 18. gününde $24.1 \pm 3 \mu \mathrm{gr} / \mathrm{mg}$ K.A., olurken, kuraklık stresi grubunun 6 . gününde $14.8 \pm 3 \mu \mathrm{gr} / \mathrm{mg}$ K.A. 18. gününde $12.9 \pm 2 \mu \mathrm{gr} / \mathrm{mg}$ K.A. bulunmuş, Stres + Potasyum tetraborat tetrahidrat uygulamalarında ise kontrolün 6 . gününde $26.4 \pm 2$ $\mu \mathrm{gr} / \mathrm{mg} \mathrm{K}$.A. 18. gününde $28.5 \pm 2 \mu \mathrm{gr} / \mathrm{mg} \mathrm{K}$.A. olduğu ölçülmüştür (Tablo 4). Potasyum tetraborat tetrahidratlı ortamda yetişen soya yapraklarının $\mathrm{Mg}^{+}$düzeyinin kontrole ve diğer uygulama ortamlarına göre anlamlı derecede yüksek bulunmuştur. Magnezyum miktarının yüksek bulunması klorofil sentezine, dolayısı ile fotosentez ürünlerinin artışına neden olacağı belirtilmiştir [32].

\section{Tartışma ve Sonuç}

Kuraklık stresi değişik bitkilerde birçok araştırıcı tarafından çalışılmıştır [33, 34, 5]. Kuraklık stresinin bor bileşikleriyle beraber soyanın özgül yaprak ağırlı̆̆ını yaklaşık \% 25-35 daha azalttığı rapor edilmiştir [35]. Dolayısı ile kuraklık stresinin klorofil oranıyla negatif ilişsili olabileceği düşünülmektedir. Tüm ölçümlerde kuraklık stresiyle beraber, bor uygulaması sonucu klorofil miktarındaki azalma literatürde rapor edilen negatif ilişkiyi doğrulamaktadır [27]. Ayrıca, iyon dengesinin klorofil miktarını etkileyebileceğinden dolayı bu tür eksikliklerin dikkate alınması gerektiği vurgulanmıştır [36]. Sonuçlara göre klorofil miktarının azalması (Tablo 1) kuraklık stresinin etkisiyle, yaprak nekrozlarından kaynaklanan bir durumdur. Bu gelişme iyon veya herhangi bir besin yetersizliğinden değil tamamen kuraklık stresinden kaynaklanan bir gösterge olarak ortaya çıkmaktadır. Çalışmamızda soya yapraklarındaki klorofil oranının kuraklık stresine bağlı olarak azalması birçok araştırmayla da desteklenmektedir [37, 27, 38].

Potasyum tetraborat tetrahidratlı ortamda yetişen soya yapraklarında MDA miktarının kontrole göre düşük, kuraklık stresindeki ortamdan yüksek bulunması, borun kuraklık stresinden kaynaklanan hücre hasarını önlediği, buna karşı bir direnç oluşturduğu anlaşılmaktadır. Kuraklık stresiyle beraber MDA nın arttı̆̆ rapor edilmiştir [39 ve 40]. Bu bağlamda, mısır ve hıyarda yürütülen denemelerde kuraklık stresinin neden olduğu en karakteristik değişsikliğin MDA daki artış olduğu belirtilmiştir [29, 36]. Kuraklıkla beraber bor uygulaması MDA ile kuraklık arasında, bor ile kuraklık süresi arasında ve potasyumlu bor uygulamasıyla kuraklık stresi arasında pozitif yönde anlamlı ilişkiler tespit edilmiştir $(\mathrm{p}<0.05)$. Nitekim tüm denemelerin yürütüldüğü uygulamalar arasında, potasyum uygulanmış ortamda yetişen bitkilerde, ortalama MDA miktarının kuraklık stresindeki sonuçlardan düşük bulunması anlamlı kabul edilmektedir [41-43]. Kontrol bitkilerine göre, bor uygulanması ile MDA nın aynı kalması, stresin ortadan kalkmasıyla veya şartların iyileştirilmesiyle ve özellikle potasyumlu bor uygulamasıyla önemli ölçüde azalacağı düşünülebilir (Tablo 4).

Prolin stres şartlarında dokularda bol miktarda bulunan aminoasitlerden biri olup, bitkilerde serbest $\mathrm{O}_{2}$ radikallerinin detoksifikasyonuna katıldığı bildirilmektedir [44]. Değişik bitkilerde yapılan 
çalışmalarda stresle birlikte prolin miktarının artması, strese karşı toleransın da artacağı anlamına geldiği bildirilmiştir. Örneğin, şeker pancarında [45], kışlık kolza ve kışlık buğdayda [46] pozitif ilişki bulunmuştur. Kushad ve Yelenosky [47] bitkilerin düşük sıcaklıkta canlılığını devam ettirebilmesinde, prolin miktarının yüzde olarak artışından çok, yapraklardaki mutlak prolin miktarının daha önemli olduğunu bildirmiştir [44]. Çalışmamızda prolin içeriğinin artmasıyla birlikte kuraklığa karşı toleransın arttığı, kuraklığın ortadan kalkmasıyla, prolin miktarının azalacağı göz önüne alınırsa, bitkilerin kuraklığa bağlı oksidatif strese adaptasyonunda önemli rol oynayabileceği söylenebilir (Tablo 3). Bu sonuç prolinin stres şartlarında koruyucu bir rol üstlendiğini belirten çalışmalarla parelilik göstermektedir [45]. Prolin bitkilerde doğal olarak sentezlenen, özellikle stres şartlarında koruyucu bir rol üstlenen önemli bir hormon olarak kabul edilmektedir [44].

İyon miktarı üzerinde potasyum tetraborat tetrahidratlı bor dışındaki ortamlarda soya yapraklarında ortalama $\mathrm{Na}^{+}$değerlerinin kontrollerden yüksek olması soyanın çevresel stres faktörlerinden etkilendiği [48 ve 49] fakat borla beraber potasyumun olumlu bir etki yaptığı sonucunu ortaya çıkartmaktadır. Artan kuraklık stresine bağlı olarak bor uygulamaları sonucunda soya yapraklarında oluşan $\mathrm{Na}^{+}$içeriğindeki artış, bir hasarın göstergesidir.

Soya yapraklarında ortalama $\mathrm{K}^{+}$değerleri Potasyum tetraborat tetrahidratlı bor dışındaki ortamlarda kontrolden yüksek bulunmuştur. Potasyum tetraborat tetrahidratlı ortamda ise kontrole göre aynı olması bu ortamda soyanın çevresel stres faktörlerinden pek etkilenmediği, diğer bor bileşiklerinin olumlu bir etki yapmadığı sonucunu ortaya çıkartmaktadır. Artan kuraklık stresine bağlı olarak potasyum tetraborat tetrahidratlı bor uygulamaları sonucunda soya yapraklarında oluşan $\mathrm{K}^{+}$içeriğindeki artışın olumlu bir gösterge olduğu bildirilmiştir [11, 50]. Potasyum tetraborat tetrahidratlı bor uygulamasıyla $\mathrm{K}^{+}$ görülen önemli artış, borun ve $\mathrm{K}^{+}$un bitkinin dayanıklılığına katkıda bulunduğuna işaret ettiği belirtilmektedir [53, 28]. Diğer bor bileşiklerinin kullanıldığı ortamlarda potasyum miktarının düşük çıkmasının birkaç nedeni olabilir. 1. Ortamda bulunan diğer iyonların gereğinden fazla alınması sonucu oluşan rekabet nedeniyle $\mathrm{K}^{+}$noksanlığının ortaya çıktığı da ifade edilmektedir [52] (Shirazi ve ark., 2005). 2. Başka bir ifadeyle bitkilerdeki vejetatif büyümeye bağlı olarak $\mathrm{K}^{+}$miktarının düştüğü söylenmektedir [32]. 3. Bu durum Marschner [53] tarafindan "büyümeyle-seyrelme" olarak açıklanmıştır. 4. Potasyumun yapraklardan gövdeye ve meyveye hareketi söz konusu olduğundan, buna bağlı olarak kuraklık uygulamalarında yapraklardaki $\mathrm{K}^{+}$miktarının düşmesi beklenen bir sonuç olarak açıklanmaktadır [28].

Artan kuraklık stresine bağlı olarak Potasyum tetraborat tetrahidratlı bor uygulamaları sonucunda soya yapraklarında oluşan $\mathrm{Ca}^{++}$içeriğindeki dengeli seyir şüphesiz olumlu bir göstergedir. $\mathrm{Ca}^{++}$oranında stresin artan şiddetine göre görülen denge potasyumlu borun bitkinin dayanıklılı̆̆ına katkıda bulunduğuna, $\mathrm{Ca}^{++}$oranın dengede tutulduğuna işaret ettiği bildirilmiştir [49, 30, 31]. Çünkü kalsiyum miktarının gerginden fazla olması hücre zarı geçirgenliğini azaltacağı, düşük olması durumunda ise hücre zarı geçirgenliğinin kaybolacağı anlamına geldiği rapor edilmiştir [50].

Kuraklıkla beraber Potasyumlu bor kullanılan ortamlarda $\mathrm{Mg}^{+}$miktarı önemli ölçüde artarken, diğer bor bileşiklerinin kullanıldığı ortamda bu durum görülmemiştir. Kuraklık stresine karşı diğer bor bileşiklerinin tolerans artıııı etkisi gözlenmediğinden dolayı, yapraklardaki miktarının bu nedenle az değiştiği düşünülmektedir. Buna göre, yapraklarda ölçülen $\mathrm{Mg}^{+}$miktarı kontrolde optimum düzeylerde 
kuraklik ve bor uygulama sonucunda optimum sinırlara, potasyumlu bor uygulamalarında ise optimum sınırlarda meydana gelmiştir (Tablo 4). Embleton ve ark. [54] ve Chapman [55] tarafindan bitkiler için verilen optimum $\mathrm{Mg}^{+}$miktarı 14-30 $\mu \mathrm{g} / \mathrm{mg}$ K.A. sınırlar arasında değişmektedir. Stresten kaynaklanan klorofil bozulmaları, nekrozların oluşması ve magnezyumun floemdeki hareketliliğinin minimum olmasından dolayı, $\mathrm{Mg}^{+}$miktarında görülen azalmanın beklenen bir sonuç olduğu bildirilmiştir [56-58].

Potasyum tetraborat tetrahidrat uygulmsı ile $\mathrm{Na}^{+}$ve $\mathrm{K}^{+}$oranı arasında negatif, $\mathrm{Ca}^{++}$ve $\mathrm{Mg}$ ile pozitif yönde istatistiksel olarak anlamlı derecede bir ilişsili olduğu tespit edilmiştir $(\mathrm{p}<0,01) . \mathrm{K}^{+}$ile $\mathrm{Na}^{++}$ arasında \% 39'luk negatif bir ilişki tespit edilmiş̧ir $(\mathrm{p}<0,01)$. Benzer ilişki $\mathrm{Ca}^{+}$ile $\mathrm{K}^{+}$arasında $\% 25^{\prime}$ lik, $\mathrm{Mg}^{+}$ile $\mathrm{K}^{+}$arasında \% 50'lik ve $\mathrm{Mg}^{+}$ile $\mathrm{Ca}^{++}$arasında \% 23'lük oranda anlamlı tespitler yapılmıştır $(\mathrm{p}<0.05) . \mathrm{Mg}^{+}$ile $\mathrm{Na}^{+}$arasında ise \% 37'lik çok anlamlı bir ilişki bulunmuştur $(\mathrm{p}<0.05)$. Dolayısıyla görülüyor ki bu değişkenlerden biri arttığında diğeri azalmıştır (Tablo 4).

Kuraklık stresinde klorofil seviyesi azalmış, MDA ve prolin miktarı artmış, her bir ortamın değişik oranlarda etkilendikleri ve strese karşı değişik tepkiler verdikleri belirlenmiştir. Stres şartlarında bitkilerin stomalarını kapatarak [59] fotosentez aktivitesini en düşük seviyeye indirdiği, bunun strese karşı koruyucu bir mekanizma olduğu, stoma hareketlerinin yapraktaki birçok fizyolojik ve biyokimyasal olayla bağlantılı olduğu sonucuna varılmıştır.

Sonuç olarak, kuraklığa karşı bor bileşiklerinin uygulanması amacıyla yapılan araştırmada, soya bitkisinin bor bileşiklerine karşı tolerans aralığının çok dar olduğu anlaşılmaktadır. Kuraklık stresinden kaynaklanan hasarın Potasyum tetraborat tetrahidratlı ortamda pek etkili olmadığı görülmüştür. Diğer borlu ortamlarda kuraklık stresine karşı aynı direncin gösterilmediği anlaşılmaktadır. Çünkü seçim çalışmalarında belirlenen eşik $(0.1 \mathrm{mg} / \mathrm{l})$ değerinin altında veya üstünde ki uygulamalar istenen sonucu vermemektedir. Çok az bir miktar doz aşımında toksik etki, çok az bir miktar doz altında verilmesi herhangi bir belirtinin oluşmadığını göstermiştir. Dolayısıyla potasyum tetraboratın $0.1 \mathrm{mg} / \mathrm{l} \mathrm{doz}$ uygulamasının en uygun eşik değeri olduğu ve kuraklığa karşı tüm parametrelerde en iyi sonucu verdiği anlaşılmıştır.

\section{Kaynaklar}

[1] Ashraf M ., "Breeding for salinity tolerance in plants" Critical Reviews in Plant Sciences 13(1) 17-42 1994.

[2] Ashraf M. ve Foolad M.R ., "Roles of Glycine Betaine ve Proline in Improving Plant Abiotic Stress Resistance”. Envionmental ve Experimental Botany 59: 206-216 2007.

[3] Khanna-Chopra R ., Selote DS ., "Acclimation to Drought Stres Generates Oxidative Stress Tolerance in Drought Resistant than-Susceptible Wheat Cultivar Under Field Conditions" Environmental ve Experimental Botany 60: 276-283 2007.

[4] Mut Z Akay H ve Aydın N ., "Effects of Seed Size ve Drought Stress on Germination ve Seedling Growth of Some at Genotypes (Avena sativa L.)". African Journal of Agricultural Research 5(10): 1101-1107 2010.

[5] Aykanat S Semercioğlu T ., Baryt H ., "1999-2007 Yılları arasındaki kurak dönemlerin Ceyhan99 buğdayındaki olumsuz etkileri”. Türkiye VIII. Tarla Bitkileri Kongresi 19-22 Ekim HatayTürkiye 2009. 
[6] Kutlu I. ve Kinaci G ., "Evaluation of Drought Resistance Indicates for Yield ve Its Components in Three Triticale Cultivars” Tekirdăg Ziraat Fakültesi Dergisi 7(2): 95-103 2010.

[7] Ashraf M. ve Iram A ., "Drought Stress Induced Changes in Some Organic Substances in Nodules ve Other Plant Parts of Two Potential Legumes Differing in Salt Tolerance”. Flora 200: 535-546 2005.

[8] Taban S. and Katkat A.V ., "Effect of salt stress on growth and mineral elements concentrations in shoots and roots of maize plants" Tarım Bilimleri dergisi 6(2): 119-122 2000.

[9] Bayrak H ., Önder M. Gezgin S ., "Bor Uygulamalarının Nohut (Cicer arietinum L.) Çeşitlerinde Verim ve Bazı Verim Unsurlarına etkileri”. S. Ü. Ziraat Fakültesi Dergisi 19 (35): 66-74 2005.

[10] Bowen J.E. ve Gauch H.G ., "Essentiality of Boron for Dryopteris dentata and Selaginella apoda" American Fern Journal 55: 67-73 1965.

[11] Soy M ve Güneş A ., Fosforun Domates (Lycopersicon esculentum L.) Bitkisinde Bor Toksisitesini Önlemede Etkisi. Tarım Bilimleri Dergisi 9 (3): 273-277 2003.

[12] Blevins D.G. and Lukaszewski K .,M ., Boron in Sturucture and Function Annual Rev. Plant Physilogy Plant Molecular Biology 49: 481-500 1998.

[13] Punchana S ., Jamjod S. And Rerkasem B ., Response to Boron Toxicity in Boron Efficient and Inefficient Wheat Genotyps 4. Int. Crop Sci. Cong ., Sept. Brisbane Australia. 2004.

[14] Hamurcu M ., Harmankaya M ., Soylu S ., Gökmen F ., Gezgin S ., Makarnalık Buğdayın (Triticum durum L.) Bazı Besin Elementleri Kapsamına Farklı Dozlarda Bor ve Demir Uygulamalarının Etkisi. Süleyman Demirel Üniversitesi Ziraat Fakültesi Dergisi 20(38): 1-8 2006.

[15] Choi E ., Kolesik P ., McNeill A ., Collins H ., Zhang Q ., Huynhi B ., Graham R. and Stangoulis J ., The Mechanism of Boron Tolerance for Maintanance of Root Growth in Barley (Hordeum vulgare L.) Plant Cell and Environment 30: 984-993 2007.

[16] Nable R.O ., Banuelous S.G. and Paull G.J ., Boron Toxicity Plant and Soil 198:181-198 1997.

[17] Garcia-Gonzalez M ., Mateo P ., Borilla I ., Effects of Boron Deficiency on Photosynthesis and Reductant Sources and Relationship with Nitrogenase Activity in Anabaena PCC 711 Plant Physiol 93: 560- 5651990.

[18] Ellis R.H ., Roberts E.H ., Summerfield R.J. ve Cooper J.P ., Environmental control of flowering in barley (Hordeum vulgare L.). II. Rate of development as a function of temperature ve photoperiod ve its modification by low temperature vernelization Annals of Botany 62: 145-158 1988.

[19] Hoagland D.R. ve Arnon D.I ., The water culture method for growing plants without. Soil. Circ. Calif. Agr. Exp. Sta ., 347-461 1938.

[20] Luna C ., Seffino L.G ., Arias C. ve Taleisnik E ., Oxidative stress indicators as selection tools for salt tolerance in Chloris gayana Plant Breeding 119: 341-345 2000.

[21] Lutts S ., Kinet J.M. ve Bouharmont J ., NaCl-Induced senesence in leaves of rice (Oryza sativa L.) cultivars differing in salinity resistance Annals of Botany 78: 389-398 1996.

[22] Taleisnik E ., Peyrano G ve Arias C ., Response of Chloris gayana cultivars to salinity 1. Germination ve early vegetative growth Trop. Grassl 31: 232-240 1997. 
[23] Bates L. S ., Waldren R.P. ve Teare I.D ., Rapid determination of free proline for water- stres studies. Plant ve Soil 39: 205-207 1973.

[24] Güneş A. ve Alpaslan M ., Boron uptake ve toxicity in maize genotypes in relation to boron and phosphorus supply. J. Plant Nutr., 23 (4): 451-550 2000.

[25] Güneş A ., Ekmeklik (T. aestivum) ve makarnalık (T. durum) buğday genotiplerinin bor alımı üzerine fosforun etkisi. Ankara Üniv. Ziraat Fak. Tarım Bilimleri Dergisi 6 (4): 44-48 2000.

[26] Alpaslan M. and Güneş A ., Interactive effects of boron ve salinity stress on the growth membrane permeability ve mineral composition of tomato ve cucumber plants. Plant and Soil 236: 123-128 2001 .

[27] Murillo-Amador B ., Jones H.G ., Kaya C ., Aguilar R.L ., Garcia-Hernveez J.L ., TroyoDieguez E ., Avila-Serrano N.Y. Rueda-Puente E ., Effects of foliar application of calcium nitrate on growth ve physiologyical attributes of cowpea (Vigna unguicculata L. Walp.) grown under salt stres. Environmental ve Esperimental Botany 58: 188-1962006.

[28] Alfocea F.P ., Estan M.T ., Caro M. and Bolarin M.C ., Response of tomato cultivars to salinity Plant and Soil 150: 203-211 1993.

[29] Hernandez J.A. ve Almansa M.S ., Short-term effects of salt stress on antioxidant systems and leaf water relations of pea leaves. Physiologia Plantarum 115(2): 251-257 2002.

[30] Doğan M ., Kılıç H ., Aktan A ., Can E.N ., Tuz stresi altındaki domates (Lycopersicon sp.) fidelerinde kalsiyum miktarı değişimleri. Ftrat Üniversitesi Fen Bilimleri Dergisi 21(2): 1031082009.

[31] Doğan M ., Tipırdamaz R ., Demir Y ., Salt resistance of tomato species grown in sand culture Plant Soil Environ ., 56(11): 499-507 2010b.

[32] Lopez M.V. and Satti S.M.E ., Calcium and potassium-enhanced growth and yield of tomato under sodium chloride stress Plant Science 114: 19-27 1996.

[33] Öztürk A ., Kuraklığın Kışlık Buğdayın Gelişmesi ve Verimine Etkisi. Turksh Journal of Agriculture ve Forestry 23: 531-540 1999.

[34] Kalefetoğlu T. ve Ekmekçi Y ., The effects of drought on plants ve tolerance mechanisms (Review). Gazi Üniversitesi Fen Bilimleri Dergisi 18(4): 723-740 2005.

[35] Katerji N ., Van-Hoorn J.W ., Hamdy A ., Mastrorilli M ., Response of tomatoes a crop of indeterminate growth to soil salinty. Agricultural water Management 38: 59-68 1998.

[36] Munne-Bosch S. ve Penuelas J ., Photo-ve Antioxidative Protection During Summer Leaf Senescence in Pistacia lentiscus L. Grown under Mediterranean Field Conditions. Annals of Botany, 92(3): 385-391 2003.

[37] Lichtenhaler HK ., Vegetation stress: an introduction to the stress concept in plants. Journal of Plant Physiology 148: 4-14 1996.

[38] Islam S ., Malik A.I ., Islam A.K.M.R. and Colmer T.D ., Salt tolerance in a Hordeum marinumTriticum aestivum amphiploid ve its parents Journal of Experimental Botany 58: 1219-1229 2007.

[39] Valenzuela A ., The biological significanc of malondialdehtde determination inthe asessment of tissuee oxidative stres. Life Sciences 48: 301-309 1990. 
[40] Hodges D.M ., Delong J.M ., Forney C.F ., Prange R.K ., Improving the thiobarbituric acidreactive-substances assay for estimating lipid peroxidation in plant tissues containing anthocyanin ve other interfering compounds. Planta 207: 604-611 1999.

[41] Shalata A. ve Tal M ., The effect of salt stress on lipid peroxidation ve antioxidants in the leaf of the cultivated tomato ve its wild salt-tolerant relative Lycopersicon pennellii Physiol Plant 104: 169-174 1998.

[42] Arıbaykal Ş. ve Öncel I ., Buğday Fidelerinin Bor Toksisitesine Toleransında Çözünür Fenolik ve Çözünür Protein Miktarındaki Değişimler. Cumhuriyet Üniversitesi Fen-Edebiyat Fakültesi Fen Bilimleri Dergisi 27(1): 13-25 2006.

[43] Başalp A ., Öncel I ., Koç E ., Bor (B) Toksisitesine Toleranslı ve Duyarlı Buğday Fidelerinde Bazı Fizyolojik ve Biyokimyasal Değişimlerin Belirlenmesi. Süleyman Demirel Üniversitesi Fen Bilimleri Enstitüsü Dergisi 15(3): 135-141 2011.

[44] Knörzer O.C ., Lederer B ., Durner J ., Böger P ., Antioxidative defense activation in soybean cells. Physiologia Plantarum 107: 294-302 1999.

[45] Cherki G ., Foursy A. ve Fares K ., Effects of salt on growth inorganic ions ve proline accumulation in relation to osmotic adjustment in five sugar beet cultivars. Enviromental and Experimental Botany 47: 39-50 2002.

[46] Stefl M. Tracka I. ve Vratny P ., Proline biosynthesis in winterplants due to exposure to low temperatures. Biol. Plant ., 20: 119-128 1978.

[47] Kushad M.M. ve Yelenkosky G. Evaluation of polyamine ve proline levels during low temperature acclimation of citrus. Plant physiol. 84: 692-695 1987.

[48] Caines A.M. and Shennan C., Interacti ve effects of $\mathrm{Ca}^{+2}$ and differing in $\mathrm{Ca}^{+2}$ use efficiency Plant Physiol Biochem ., 37(7/8): 569-576, 1999.

[49] Bondada B.R ., Syvertsen J.P. ve Albrigo L.G ., Urea nitrogen uptake by citrus leaves. Hort. Science 36: 1061-1066 2001.

[50] Yağmur M ., Kaydan D ., Okut N ., Potasyum Uygulamasının Tuz Stresindeki Arpanın Fotosentetik Pigment İçeriği Ozmotik Potansiyel $\mathrm{K}^{+} / \mathrm{Na}^{+}$Oranı ile Bitki Büyümesindeki Etkileri. Ankara Üniversitesi Ziraat Fakültesi Tarım Bilimleri Dergisi 12 (2): 188-194 2006.

[51] Din C ., S. M. Mehdi M. Sarfraz Hassan Ghulam and M. Sadiq Comparative efficiency of foliar ve soil application of $\mathrm{K}$ on salt tolerance in rice. Pakistan Journal of Biological Sciences 4: 815-817 2001.

[52] Shirazi M.U ., M. Y. Ashraf M. A. Khan ve M. H. Naqvi. Potassium induced salinity tolerance in wheat (Triticum aestivum L.). Int. J. Environ. Sci. Tech ., 2: 233-236 2005.

[53] Marschner H. Mineral nutritions of higher plants. Academic Pres. London GB. 1995.

[54] Embleton T.W. and Jones W.W.. Foliar-Applied nitrogen for citrus fertilization. J. Environ. Quality. 3 (4): 388-391 1974.

[55] Chapman H.D ., The mineral nutrition of citrus. Plant Physiol. 17: 333-335 1976.

[56] Çakmak I ., Römheld V ., Boron Deficiency-Induced Impairments of Cellular Functions in Plants Plant ve Soil 193: 71-83 1997. 
[57] Ben Amor N. Jimenez A ., Megdiche W ., Lundqvist M ., sevilla F ., Abdelly C ., Response of antioxidant systems to $\mathrm{NaCl}$ stres in the halophyte Cakile maritima. Physiologia Plantarum 126: 446-457 2006.

[58] Yağmur B ., Farklı Seviyelerde Uygulanan Potasyumun Anasonun Verim ve Yaprak Besin Maddesi İçeriğine Etkisi. Ege Üniversitesi Ziraat Fakültesi Dergisi 46 (1): 17-24 2009.

[59] Alıcı Y. ve Öncel I ., Buğdayda Bor Toksisitesi ile Fosfor Arasındaki Etkileşimin Büyüme ve Çözünür Karbonhidratlar ile ilişkisinin incelenmesi. Cumhuriyet Üniversitesi Fen-Edebiyat Fakültesi Fen Bilimleri Dergisi 29(1): 29-46 2008. 